Bedankt voor het downloaden van dit artikel. De artikelen uit de (online)tijdschriften van Uitgeverij Boom zijn auteursrechtelijk beschermd. U kunt er natuurlijk uit citeren (voorzien van een bronvermelding) maar voor reproductie in welke vorm dan ook moet toestemming aan de uitgever worden gevraagd.

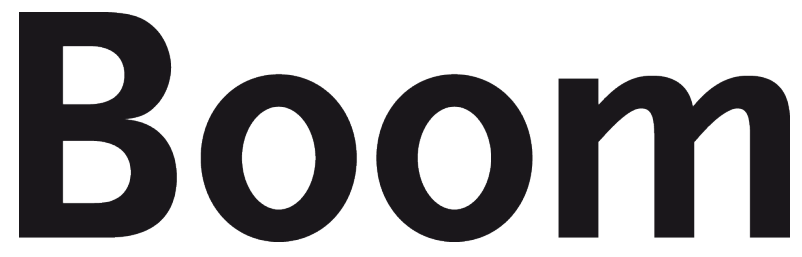

Behoudens de in of krachtens de Auteurswet van 1912 gestelde uitzonderingen mag niets uit deze uitgave worden verveelvoudigd, opgeslagen in een geautomatiseerd gegevensbestand, of openbaar gemaakt, in enige vorm of op enige wijze, hetzij elektronisch, mechanisch door fotokopieën, opnamen of enig andere manier, zonder voorafgaande schriftelijke toestemming van de uitgever.

Voor zover het maken van kopieën uit deze uitgave is toegestaan op grond van artikelen $16 \mathrm{~h} \mathrm{t} / \mathrm{m} \mathrm{16m}$ Auteurswet 1912 jo. Besluit van 27 november 2002, Stb 575, dient men de daarvoor wettelijk verschuldigde vergoeding te voldoen aan de Stichting Reprorecht te Hoofddorp (postbus 3060, 2130 KB, www.reprorecht.nl) of contact op te nemen met de uitgever voor het treffen van een rechtstreekse regeling in de zin van art. 16l, vijfde lid, Auteurswet 1912.

Voor het overnemen van gedeelte(n) uit deze uitgave in bloemlezingen, readers en andere compilatiewerken (artikel 16, Auteurswet 1912) kan men zich wenden tot de Stichting PRO (Stichting Publicatie- en Reproductierechten, postbus 3060, 2130 KB Hoofddorp, www.cedar.nl/pro).

No part of this book may be reproduced in any way whatsoever without the written permission of the publisher.

info@boomamsterdam.nl www.boomuitgeversamsterdam.nl 


\section{Baanonzekerheid en mentaal welzijn: gemedieerd door de bedreiging van Jahoda's functies van werk?}

Stefanie Margerin, Tinne Vander Elst, Hermina Van Coillie, Heidi Verlinden \& Hans De Witte ${ }^{*}$

In deze studie onderzochten we of de negatieve samenhang tussen gepercipieerde baanonzekerheid en mentaal welzijn gemedieerd wordt door de bedreiging van Jahoda's manifeste functies (bijv. inkomen) en latente functies (bijv. sociaal contact en status) van werk. De ervaren bedreiging van het verliezen van de huidige baan houdt immers tevens een bedreiging in van de functies die werk kan vervullen, wat het welzijn van werknemers kan verminderen. Specifiek wilden we de resultaten van Selenko en Batinic (2013) en Vander Elst, Näswall, Bernhard-Oettel, De Witte en Sverke (2016) repliceren, gebruikmakend van een andere steekproef en methodologie. In totaal namen 788 werknemers uit België deel aan een cross-sectionele vragenlijststudie. De resultaten toonden aan dat baanonzekerheid negatief samenhing met mentaal welzijn. De bedreiging van zowel de manifeste als latente functies van werk medieerden zoals verwacht het verband tussen baanonzekerheid en mentaal welzijn, en dit in ongeveer gelijke mate. Deze resultaten sluiten goed aan bij de resultaten uit voorgaande studies en valideren het belang van de bedreiging van de functies van werk als verklaring voor de negatieve relatie tussen baanonzekerheid en mentale gezondheid. Onze bevindingen kunnen de ontwikkeling van interventiestrategieën stimuleren om het negatieve verband tussen baanonzekerheid en mentaal welzijn af te zwakken, zoals het aansporen tot deelname aan sociale activiteiten buiten het werk.

\section{Inleiding}

De laatste decennia was baanonzekerheid - verwijzend naar de onzekerheid over de aard en het voortbestaan van de huidige baan in de toekomst - een populair

* Stefanie Margerin werkte deze studie uit als onderdeel van haar masterproef binnen de afstudeerrichting Arbeids- \& Organisatiepsychologie aan de Faculteit Psychologie en Pedagogische Wetenschappen van de KU Leuven, België. Correspondentieadres: Arbeids- \& Organisatiepsychologie \& Opleidingskunde (OE), Dekenstraat 2 - bus 3725, 3000 Leuven, e-mail: StefanieMargerin@hotmail.com. Tinne Vander Elst werkt in het Knowledge, Information and Research center (KIR) van Groep IDEWE, België, en is verbonden aan de onderzoeksgroep Arbeids-, Organisatie- en Personeelspsychologie, Faculteit Psychologie en Pedagogische Wetenschappen, KU Leuven, België. Hermina Van Coillie en Heidi Verlinden zijn werkzaam bij het Securex studiecentrum, HR Research. Hans De Witte is verbonden aan de onderzoeksgroep Arbeids-, Organisatie- en Personeelspsychologie, Faculteit Psychologie en Pedagogische Wetenschappen, KU Leuven, België, en Optentia Research Focus Area, Vaal Triangle Campus, North-West University, Zuid-Afrika. 
onderzoekstopic (Shoss, 2017). Uit de onderzoeksliteratuur blijkt dat baanonzekerheid negatieve gevolgen met zich meebrengt, zoals een lager mentaal welzijn (De Witte, Vander Elst \& De Cuyper, 2015). Voor deze relatie bestaan in de literatuur verschillende verklaringen, zoals de bedreiging (met het verlies) van de functies (of voordelen) van werk (De Witte, 1999; Selenko \& Batinic, 2013).

Baanbrekend waren de inzichten in het Latente Deprivatiemodel van Jahoda (1982). Jahoda suggereerde dat betaalde arbeid een aantal functies vervult die cruciaal zijn voor werkenden, onderverdeeld in manifeste functies (bijv. inkomen) en latente functies (bijv. sociaal contact en status). Het wegvallen van werk zorgt ervoor dat deze functies niet langer vervuld worden en dat resulteert in een verlaging van het mentaal welzijn (Jahoda, 1982). Recentere studies over baanonzekerheid bouwden hierop verder. Zo vonden Selenko en Batinic (2013) dat de mate waarin de manifeste en latente werkfuncties vervuld zijn, het verband tussen baanonzekerheid en mentaal welzijn gedeeltelijk medieerde. Zij focusten hierbij op de perceptie van de huidige toegang tot de functies van werk: de mate waarin personen aan het werk waren en daardoor konden genieten van de voordelen van werk (zoals sociaal contact en structuur). Vander Elst, Näswall, Bernhard-Oettel, De Witte en Sverke (2016) vonden in hun onderzoek dat percepties van de toekomstige toegang tot de latente functies van werk - of de bedreiging van de latente werkfuncties in de toekomst - het verband tussen baanonzekerheid en mentaal welzijn medieerden. Dit verband bleek echter niet significant gemedieerd te worden door bedreiging van de manifeste functies van werk.

Het is belangrijk om de robuustheid van bovenstaande wetenschappelijke bevindingen aan te tonen. Daarom werd in de huidige studie getracht om de besproken bevindingen te repliceren. We gebruikten daarbij een andere methodologie (andere meetinstrumenten en een cross-sectioneel onderzoeksdesign) en een andere steekproef (heterogene steekproef van Belgische werknemers). Replicatiestudies zijn belangrijk voor theorievorming en voor de praktijk. Vooraleer er interventies kunnen worden uitgewerkt, dient er immers zekerheid te zijn over de rol van de besproken werkfuncties als onderliggend verklarend mechanisme. Bijkomend onderzochten we in deze studie welk type bedreiging van werkfuncties (latent of manifest) de sterkste mediator vormt in het verband tussen baanonzekerheid en mentaal welzijn. Dit laatste werd nog niet eerder onderzocht.

\section{Literatuurstudie}

\subsection{Definitie van baanonzekerheid}

Baanonzekerheid kan gedefinieerd worden aan de hand van verschillende kenmerken. In de eerste plaats betreft baanonzekerheid de onzekerheid over de continuïteit van de huidige baan in de toekomst (Van Vuuren, 1990). Werknemers zijn onzeker over de aard en het voortbestaan van hun baan. Het gaat hierbij om een subjectieve perceptie: éénzelfde objectieve situatie kan door werknemers op verschillende manieren geïnterpreteerd worden (Greenhalgh \& Rosenblatt, 1984). Daarbij kan een onderscheid worden gemaakt tussen kwalitatieve en kwantitatieve baanonzekerheid (Hellgren, Sverke \& Isaksson, 1999). Kwantitatieve baan- 
onzekerheid omvat de onzekerheid over het voortbestaan van de baan in zijn geheel: men vreest ontslagen te worden. Kwalitatieve baanonzekerheid omvat onzekerheid over het behoud van gewaardeerde werkkenmerken zoals loon, carrièremogelijkheden en werkinhoud (Handaja \& De Witte, 2006). In deze studie focussen we op kwantitatieve baanonzekerheid: de werknemer vreest om zijn/ haar baan te verliezen.

\subsection{Definitie van mentaal welzijn}

Het is niet eenvoudig om mentaal welzijn eenduidig te definiëren. In de General Health Questionnaire (Goldberg, 1978), een internationaal gevalideerd meetinstrument, verwijst mentaal welzijn naar een goed concentratie- en slaapvermogen, zelfvertrouwen, geluksgevoelens en weinig depressieve of angstgevoelens (Baksheev, Robinson, Cosgrave, Baker \& Yung, 2011). In de Mental Health Inventory (MHI; Berwick et al., 1991) verwijst mentaal welzijn naar de afwezigheid van gevoelens van angst en depressie, een goede controle over het gedrag en de emoties, positieve affectiviteit en goede emotionele relaties (Berwick et al., 1991). Vooral het ervaren van weinig angst- en depressieve gevoelens blijkt kenmerkend te zijn voor mentaal welzijn. In onze studie hanteren we een engere definitie van mentaal welzijn en focussen we op de beleving van (weinig) depressieve gevoelens.

\subsection{Relatie tussen baanonzekerheid en mentaal welzijn}

Uit de literatuur blijkt dat baanonzekerheid een belangrijke stressor is op het werk (Cheng \& Chan, 2008), met negatieve gevolgen voor de werknemer en de organisatie. Uit de studie van Handaja en De Witte (2006) in de bankensector bleek dat baanonzekerheid samenhing met een beduidend lagere arbeidstevredenheid en hogere burnoutscores. Daarnaast vonden ze dat baanonzekerheid, en dan vooral de kwantitatieve variant, gerelateerd was aan lagere scores op mentaal welzijn en psychosomatische klachten zoals hoofdpijn en duizeligheid. Ook uit de metaanalyses van Sverke, Hellgren en Näswall (2002) en Cheng en Chan (2008) kwam naar voren dat baanonzekerheid negatief samenhangt met positieve werkattitudes (zoals arbeidstevredenheid en werk-betrokkenheid), positieve attitudes ten opzichte van de organisatie (zoals het vertrouwen in de organisatie en organisatiebetrokkenheid), en fysiek en mentaal welzijn.

Wat de richting van het verband tussen baanonzekerheid en mentaal welzijn betreft, hebben verschillende longitudinale studies aangetoond dat baanonzekerheid het mentaal welzijn door de tijd heen beïnvloedt (Dekker \& Schaufeli, 1995; Ferrie, Shipley, Marmot, Stansfeld \& Smith, 1995; Hellgren \& Sverke, 2003). In een recente overzichtsstudie werd dan ook evidentie gevonden voor de stelling dat baanonzekerheid het mentaal welzijn negatief beïnvloedt (De Witte, Pienaar \& De Cuyper, 2016). Voor een wederkerige relatie tussen baanonzekerheid en mentaal welzijn werd slechts beperkte evidentie gevonden.

Aangezien vanuit de literatuur blijkt dat baanonzekerheid en mentaal welzijn op negatieve wijze samenhangen, voorspellen we ook in deze studie een negatief verband tussen baanonzekerheid en mentaal welzijn. 
Hypothese 1 ( $\left.\mathrm{H}_{1}\right)$ : Er is een negatief verband tussen baanonzekerheid en mentaal welzijn.

\subsection{Latente Deprivatie Model van Jahoda}

De volgende vraag die we ons stellen, is via welke processen de relatie tussen baanonzekerheid en mentaal welzijn verloopt. In deze studie onderzochten we bedreiging van de functies van werk als een mogelijke verklaring, in navolging van Selenko en Batinic (2013) en Vander Elst et al. (2016). Hiervoor baseerden we ons op het Latente Deprivatie Model van Jahoda (1982), zoals dat kan worden toegepast op baanonzekerheid (De Witte, 1999).

Volgens het Latente Deprivatie Model (Jahoda, 1982) vervult werk (betaalde arbeid) een aantal functies die cruciaal zijn voor het mentaal welzijn van mensen. Het wegvallen van deze werkfuncties heeft dan ook een negatieve invloed op hun mentaal welzijn. In de eerste plaats verschaft arbeid een inkomen (Jahoda, 1982). Dat inkomen wordt verworven door het leveren van inspanningen. Het gaat hierbij om een ruilverhouding: de werknemer zet zich in en investeert tijd en energie in het werk en krijgt hiervoor in ruil een inkomen. Het inkomen vormt de manifeste functie van het werk. Deze functie van werk is voor iedereen zichtbaar.

De latente functies van werk zijn minder opvallend (Muller, Creed, Waters \& Machin, 2005). Jahoda onderscheidt vijf soorten latente werkfuncties (Jahoda, 1982). Ten eerste zorgt arbeid voor het structureren van de tijd. Er ontstaat afwisseling tussen dagen waarop gewerkt wordt en dagen waarop niet gewerkt wordt. Ook de dag zelf wordt gestructureerd. Wanneer het werk wegvalt, valt die structuur grotendeels weg. Dit kan leiden tot eentonigheid en verveling. Ten tweede vormt arbeid een belangrijke bron van sociale contacten en ervaringen buiten de gezinskring. Zo kun je contacten leggen met bijvoorbeeld collega's en klanten. Bij werkloosheid vallen deze sociale contacten gedeeltelijk weg. Ten derde zorgt arbeid voor de mogelijkheid om een bijdrage te leveren aan de samenleving (collectief doel). Dit geeft het gevoel een zinvol leven te leiden. Wanneer het werk wegvalt, kan men zich overbodig voelen en het gevoel hebben er niet meer bij te horen. Ten vierde levert arbeid status en identiteit. We zijn wat we doen. Indien men geen werk meer heeft, kan dit leiden tot een verlaagd zelfwaardegevoel en schaamtegevoelens. Ten vijfde zorgt arbeid voor activiteit ('enforced activity'). Je doet de dingen die je moet doen, zonder dat iemand je daarvoor moet stimuleren en je kunt een evenwicht vinden tussen verantwoordelijkheden en vrije tijd. Bij het verliezen van de baan valt ook deze laatste functie van werk weg.

Selenko en Batinic (2013) onderzochten het mediatie-effect van de manifeste en latente functies van werk in het negatieve verband tussen baanonzekerheid en mentaal welzijn. Zij bestudeerden hierbij de mate waarin mensen in het heden toegang denken te hebben tot de functies van werk. Ze vonden dat de negatieve relatie tussen baanonzekerheid en mentaal welzijn partieel gemedieerd werd door de (huidige) deprivatie van de functies van werk, waarbij baanonzekerheid voornamelijk gerelateerd bleek te zijn aan verminderde financiële voordelen. Wanneer werknemers onzeker zijn over hun baan, hebben ze echter nog steeds toegang tot de functies van werk (zoals inkomen en sociaal contact), omdat ze op dat moment nog beschikken over hun baan (Vander Elst et al., 2016). In onze studie kijken we 
daarom naar de mate waarin mensen denken in de nabije toekomst toegang te hebben tot de functies van werk.

Baanonzekerheid betekent dat mensen het gevoel hebben dat hun baan wordt bedreigd. Hierbij worden ook de functies die samenhangen met de baan bedreigd. Volgens de Conservation of Resources Theory van Hobfoll (2001) zijn mensen steeds gericht op het verkrijgen en behouden van hulpbronnen (bijvoorbeeld functies van werk). Indien ze het gevoel hebben deze hulpbronnen kwijt te kunnen raken, dan beïnvloedt dit hun mentaal welzijn op negatieve wijze. Vanuit deze insteek voorspellen we dat de gepercipieerde bedreiging van de werkfuncties negatief samenhangt met het mentaal welzijn.

In lijn met deze redenering onderzochten Vander Elst et al. (2016) of de bedreiging van de manifeste en latente werkfuncties de relatie tussen baanonzekerheid en mentale en fysieke gezondheidsklachten medieerden. Ze stelden inderdaad een dergelijk mediatie-effect vast. De bedreiging van de manifeste functie van werk medieerde in hun studie echter alleen de relatie tussen baanonzekerheid en fysiek welzijn. De bedreiging van de latente functies van werk medieerde zowel de relatie tussen baanonzekerheid en fysiek welzijn als de relatie tussen baanonzekerheid en mentaal welzijn.

Ook in de huidige studie focussen we op de mediërende rol van de bedreiging van de functies van werk in de toekomst (vgl. Vander Elst et al., 2016) in plaats van de huidige toegang tot de functies van werk (vgl. Selenko \& Batinic, 2013). We willen de studieresultaten van Vander Elst et al. (2016) repliceren, waarbij we gebruikmaken van een heterogene steekproef, andere meetinstrumenten en een ander studiedesign. Terwijl de studie van Vander Elst et al. (2016) uitsluitend gericht was op de Vlaamse bevolking, namen aan deze studie ook Waalse en Brusselse werknemers deel. Daarnaast werd in de studie van Vander Elst et al. (2016) elke latente functie van werk slechts met één item onderzocht, terwijl we in de huidige studie twee items per latente functie van werk gebruiken. Dit kan de betrouwbaarheid van de meting vergroten. Tot slot gebruikten Vander Elst et al. (2016) een intra-individuele onderzoeksopzet, terwijl de verbanden in deze studie onderzocht zullen worden via een cross-sectioneel design. Een mogelijke replicatie in deze studie met een iets andere methodologie en een heterogene steekproef zou de robuustheid en daarmee ook de ruimere generalisatie van de studieresultaten kunnen aantonen.

Op basis van de gepresenteerde theoretische redeneringen en empirische bevindingen komen we tot de volgende hypothese:

Hypothese 2 ( $\mathrm{H}_{2}$ ): De negatieve relatie tussen baanonzekerheid en mentaal welzijn wordt gemedieerd door de bedreiging van de manifeste ( $\mathrm{H}_{2 \mathrm{a}}$ ) en latente functies ( $\mathrm{H} 2 \mathrm{~b})$ van werk.

We stellen ons hierbij ook de vraag welke bedreiging van functies van werk de sterkste mediërende rol speelt, waarbij we focussen op de manifeste versus latente functies van werk. Op basis van voorgaande onderzoeksliteratuur kunnen we hierover nog geen uitspraak doen. 
Onderzoeksvraag 1: Welke bedreiging van functies van werk vormt de sterkste mediator in het verband tussen baanonzekerheid en mentaal welzijn?

Onze twee hypothesen worden samengevat en weergegeven in Figuur 1.

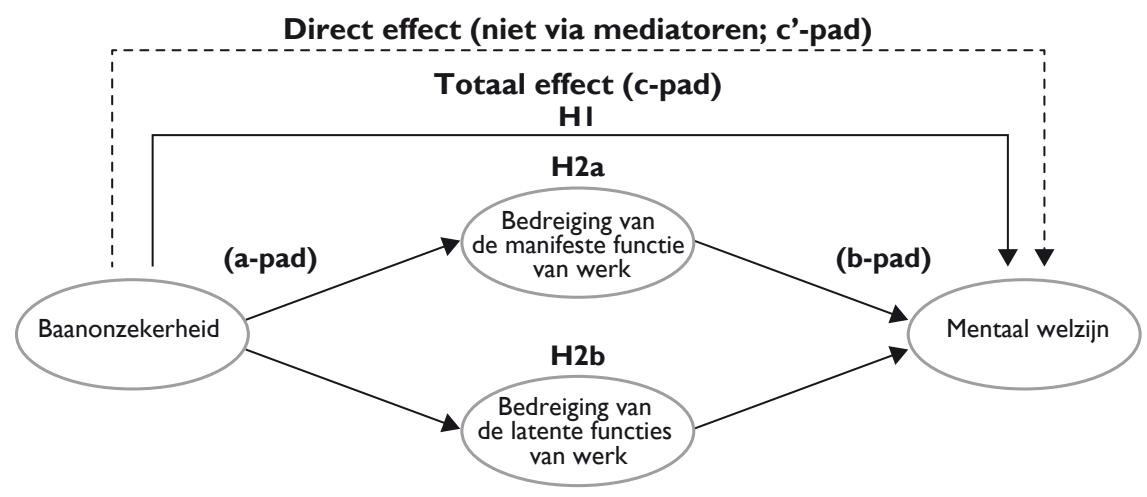

Figuur 1 Onderzoeksmodel met weergave van de twee hypothesen

\section{Methode}

\subsection{Dataverzameling en respondenten}

De data werden verzameld in 2013 in het kader van een onderzoek naar de functies van werk, baanonzekerheid, en de mogelijke gevolgen ervan (zoals burnout, presenteïsme en absenteïsme). In totaal werden 2714 leden van een onderzoekspanel van een Belgische externe dienst voor preventie en bescherming op het werk (Securex) via een mail uitgenodigd om deel te nemen aan een online vragenlijst. Door zowel Waalse, Brusselse als Vlaamse werknemers in het onderzoek te betrekken kan in de huidige studie grotere heterogeniteit inzake baanonzekerheid worden ingebracht. In Wallonië en Brussel ligt het aantal werklozen hoger, en dus ook het niveau van baanonzekerheid (De Witte \& Van den Broeck, 2011). De elektronische vragenlijst werd ingevuld door 907 personen, wat een respons geeft van $33.4 \%$. De volgende groepen werden uitgesloten tot deelname: personen jonger dan 18 jaar, studenten, werkzoekenden, gepensioneerden, zelfstandigen, huisvrouwen en -mannen, personen met een vrij beroep en personen van de categorie 'ander'. Dit resulteerde in een definitieve steekproef van 788 werknemers.

Iets meer dan de helft van de respondenten was vrouw $(57.6 \%, n=454)$, tegenover $42.4 \%$ mannen $(n=334)$. De respondenten waren gemiddeld 41 jaar oud $(S D=$ 9.91), waarbij 33.9\% van de respondenten tot de leeftijdscategorie 18-35 jaar ( $n=$ $267)$ behoorde. De overige $66.1 \%$ was ouder dan 35 jaar $(n=521)$. Wat de beroepspositie betreft, werkte $5.1 \%$ als arbeider $(n=40)$, 93.5\% als bediende (kantoorpersoneel, $n=737$ ) en $1.4 \%$ als manager $(n=11)$. Van de respondenten was $78.3 \%$ hoogopgeleid (bachelor- of masterdiploma, $n=617$ ), tegenover $21.7 \%$ laag geschoolden $(n=171)$. Ongeveer 60.5\% $(n=477)$ was afkomstig uit Vlaanderen, 24.0\% $(n=$ 
189) woonde in Brussel en 14.5\% $(n=114)$ in Wallonië. Van de 788 respondenten waren 8 personen (1\%) niet afkomstig uit België.

\subsection{Meetinstrumenten}

Om de dimensionaliteit van de variabelen na te gaan werd gebruikgemaakt van SPSS (versie 20). We voerden een principale componenten-analyse (PCA, met Varimax-rotatie) uit op de items voor kwantitatieve baanonzekerheid, mentaal welzijn, bedreiging van de manifeste functies en bedreiging van de latente functies van werk. Daarbij kwamen de verwachte dimensies naar voren, met de nuances die hieronder worden besproken.

Kwantitatieve baanonzekerheid. Kwantitatieve baanonzekerheid werd gemeten via vier items, ontleend aan De Witte (2000) en gevalideerd door Vander Elst, De Witte en De Cuyper (2014). Deze items verwijzen naar twee aspecten van baanonzekerheid (Borg \& Elizur, 1992): het affectieve aspect (bijv. 'Ik voel me onzeker over de toekomst van mijn baan') en het cognitieve aspect (bijv. 'Ik ben er zeker van dat ik mijn baan zal kunnen behouden'). De items werden beoordeeld op een 6-puntsschaal, van (1) helemaal niet akkoord tot (6) helemaal akkoord. ${ }^{1}$ Cronbach's alfa $=.93$.

Mentaal welzijn. Om mentaal welzijn te meten selecteerden we uit een 5-itemschaal (Berwick et al., 1991) drie items die betrekking hebben op (weinig) depressieve gevoelens. De items bevroegen hoe de respondenten zich de afgelopen maand voelden (bijv. 'Hoe vaak heeft u zich de afgelopen maand neerslachtig en somber gevoeld?'), beoordeeld op een 6-puntsschaal, van (1) nooit tot (6) altijd. Een hoge score op de schaal reflecteert mentaal welzijn. De Cronbach's alfa bedroeg .85 .

Bedreiging van de manifeste functie van werk. De bedreiging van de manifeste functie van werk werd gemeten aan de hand van drie items, ontleend aan Muller et al. (2005). Ze werden geherformuleerd zodat ze betrekking hebben op de nabije toekomst (bijv. 'Ik denk dat ik in de nabije toekomst voldoende geld zal hebben om mezelf extraatjes te kunnen veroorloven') in plaats van het heden (bijv. 'Ik heb voldoende geld om mezelf extraatjes te kunnen veroorloven'). Ze werden beoordeeld via een 5 -puntsschaal ( 1 = helemaal niet akkoord tot $5=$ helemaal akkoord). De items werden omgescoord, waardoor we de bedreiging van de manifeste functie van werk meten. Cronbach's alfa $=.90$.

Bedreiging van de latente functies van werk. Voor elke latente functie van werk (collectief doel, sociaal contact, status, tijdstructuur en activiteit) werden uit Muller et al. (2005) de twee items geselecteerd met de hoogste factorladingen op de onderliggende factor. De items werden geherformuleerd zodat ze betrekking hebben op de nabije toekomst (bijv. 'Ik denk dat ik in de nabije toekomst geregeld aan sociale activiteiten zal deelnemen') in plaats van het heden (bijv. het originele item: 'Ik neem geregeld deel aan sociale activiteiten'). De twee items van collectief doel betroffen de rol en positie van het individu in de samenleving (bijv. 'Ik denk dat ik me in de nabije toekomst sterk betrokken zal voelen bij de samenleving (de ruime groep mensen rondom mij)'). De twee items van sociaal contact hadden te maken met het sociaal netwerk van het individu (bijv. 'Ik denk dat ik in de nabije toekomst geregeld aan sociale activiteiten zal deelnemen'). Beide items van status 
betroffen de mate waarin het individu zich gewaardeerd voelt door anderen (bijv. 'Ik denk dat ik in de nabije toekomst vaak gewaardeerd zal worden door de mensen rondom mij'). De items van tijdstructuur betroffen de structuur van de dag en afwisseling van dagen (bijv. 'Ik denk dat ik in de toekomst vaak niets te doen zal hebben'). De items van activiteit ten slotte hadden betrekking op het vrijwillig doen van de dingen die je moet doen en het evenwicht tussen verantwoordelijkheden en vrije tijd (bijv. 'Ik denk dat ik in de nabije toekomst doorgaans de dingen zal doen die ik moet doen'). De tien items werden beoordeeld op een 5-puntsschaal ( 1 = helemaal niet akkoord tot $5=$ helemaal akkoord). Scores werden waar nodig omgescoord waardoor ze betrekking hadden op de bedreiging van de latente functies. Na PCA (met Varimax-rotatie) bleken de items voor activiteit en tijdsstructuur onvoldoende te laden op de factor 'latente functies van arbeid'. Deze items werden dan ook weggelaten uit de definitieve schaal. De schaal bedreiging van latente functies van werk betrof dus collectief doel, sociaal contact en status; allemaal functies met een sociale betekenis. De Cronbach's alfa van de uiteindelijke schaal bedroeg .82 .

\subsection{Analyses}

In de eerste hypothese werd een significante negatieve relatie tussen baanonzekerheid en mentaal welzijn voorspeld. In de tweede hypothese werd een significant mediatie-effect van de bedreiging van de manifeste ( $\left.\mathrm{H}_{2} \mathrm{a}\right)$ en latente $\left(\mathrm{H}_{2} \mathrm{~b}\right)$ functies van werk voorspeld in het verband tussen baanonzekerheid en mentaal welzijn. Met behulp van de SPSS INDIRECT-macro van Preacher en Hayes (2008) werd het verband tussen baanonzekerheid en mentaal welzijn ( $\left.\mathrm{H}_{1}\right)$ onderzocht, en werd ook het mediatie-effect van de bedreiging van de manifeste functie van werk $\left(\mathrm{H}_{2} \mathrm{a}\right)$ en de bedreiging van de latente functies van werk $\left(\mathrm{H}_{2} \mathrm{~b}\right)$ in dit verband getest.

De INDIRECT-macro verschafte ons een schatting van het verband tussen baanonzekerheid en de bedreiging van de manifeste en latente functies van werk (a-pad) en het verband tussen de bedreiging van de manifeste en latente functies van werk en mentaal welzijn (b-paden). Verder verkregen we het totale verband tussen baanonzekerheid op mentaal welzijn (c-pad) en het directe verband tussen baanonzekerheid en mentaal welzijn na controle voor de mediatoren (c'-pad), zoals weergegeven in Figuur 1. Ook de indirecte verbanden tussen baanonzekerheid op mentaal welzijn via de bedreiging van de manifeste en latente functies van werk (axb-paden) werden berekend. Met behulp van deze macro werd ook het verschil of het contrast berekend tussen de effecten van beide mediatoren. Een bijkomende confirmatorische factoranalyse in MPlus demonstreerde dat het gebruikte vier-factorenmodel (met de factoren baanonzekerheid, bedreiging van de manifeste functie, bedreiging van de latente functies, en mentaal welzijn) beter aansloot bij de data dan een alternatief één-factormodel $\left(\Delta \chi^{2}(6)=3823.76\right.$, $p<.001)$. 


\section{Resultaten}

\subsection{Beschrijvende statistieken}

In Tabel 1 worden de gemiddelden $(M)$, standaarddeviaties $(S D)$ en correlaties voor de verschillende variabelen weergegeven. Zoals verwacht hing baanonzekerheid negatief samen met mentaal welzijn, terwijl de bedreiging van de manifeste en latente werkfuncties positief samenhingen met baanonzekerheid en negatief met mentaal welzijn.

\subsection{Toetsing van de hypotheses}

De resultaten van de mediatie-analyse worden weergegeven in Tabel 2. In de eerste hypothese werd voorspeld dat baanonzekerheid significant negatief zou samenhangen met mentaal welzijn. Hiervoor keken we naar het totaalverband tussen de onafhankelijke variabele en de afhankelijke variabele (c-pad) in Tabel 2. Uit de resultaten blijkt dat baanonzekerheid zoals verwacht negatief samenhing met mentaal welzijn: $B=-0.28, p<.001$.

Hypothese 2 luidde dat de negatieve relatie tussen baanonzekerheid en mentaal welzijn op significante wijze wordt gemedieerd door de bedreiging van de manifeste $\left(\mathrm{H}_{2} \mathrm{a}\right)$ en latente $\left(\mathrm{H}_{2} \mathrm{~b}\right)$ functies van werk. Zowel voor Hypothese $2 \mathrm{a}$ als voor Hypothese $2 \mathrm{~b}$ vonden we evidentie. Hiervoor keken we naar het indirecte verband tussen de onafhankelijke variabele en de afhankelijke variabele via de voorgestelde mediatoren ( $a \times b$-paden) in Tabel 2. Het indirecte verband ( $a \times b-p a d)$ tussen baanonzekerheid en mentaal welzijn via de bedreiging van de manifeste functie van werk was significant $(B=-0.02,95 \% C I[-0.04,-0.002])$. Ook het indirecte verband ( $\mathrm{a} \times \mathrm{b}$-pad) tussen baanonzekerheid en mentaal welzijn via de bedreiging van de latente functies van werk was significant $(B=-0.04,95 \% C I[-0.06,-0.02])$. Het contrast tussen de indirecte effecten van de bedreiging van de manifeste en latente functies van werk bleek echter niet significant te zijn $(B=0.02,95 \% C I$ [-0.01, 0.05]). De bedreiging van beide soorten functies van werk vormden dus een even belangrijke verklaring voor het negatieve verband tussen baanonzekerheid en mentaal welzijn. We stelden partiële mediatie vast, aangezien baanonzekerheid nog steeds een significante samenhang vertoonde met mentaal welzijn na controle van de mediatoren (c'pad), $B=-0.23, p<.001$.

\section{Discussie}

\subsection{Samenvatting bevindingen}

In deze replicatiestudie werd voortgeborduurd op de studies van Selenko en Batinic (2013) en Vander Elst et al. (2016), die aantoonden dat het wegvallen of het bedreigd zien van de functies van werk het verband tussen baanonzekerheid en mentaal welzijn kan verklaren. Gebaseerd op het Latente Deprivatiemodel van Jahoda (1982) wilden we deze resultaten repliceren om zo de robuustheid van deze bevindingen te kunnen inschatten. We testten het verband tussen baanonzekerheid en mentaal welzijn, en of dit verband gemedieerd werd door zowel de bedreiging van de manifeste functies als de bedreiging van de latente functies van werk. 
Tabel 1 Gemiddelden, standaarddeviaties en correlaties $(N=788)$

\begin{tabular}{|c|c|c|c|c|c|c|c|c|c|}
\hline & $M$ & $S D$ & $\mathbf{I}$ & 2 & 3 & 4 & 5 & 6 & 7 \\
\hline I. $18 \mathrm{t} / \mathrm{m} 35$-jarigen ${ }^{c}$ & 0.34 & 0.47 & -.02 & $-.08 *$ & -.05 & -.05 & -.04 & -.06 & \\
\hline 2. Arbeiders ${ }^{\mathrm{b}}$ & 0.05 & 0.22 & -.01 & .03 & .05 & .01 & $.16 * *$ & & \\
\hline 3. Mannen ${ }^{a}$ & 0.42 & 0.49 & .02 & $-.08 *$ & $.08 *$ & .03 & & & \\
\hline 4. Mentaal welzijn & $4.4 I$ & 0.92 & $-.36 * *$ & $-.26 * *$ & $-.36 * *$ & & & & \\
\hline $\begin{array}{l}\text { 3. Latente functies } \\
\text { van werk }\end{array}$ & 2.42 & 0.58 & $.17 * *$ & $.38 * *$ & & & & & \\
\hline $\begin{array}{l}\text { 6. Manifeste functie } \\
\text { van werk }\end{array}$ & 2.80 & 0.98 & $.23 * *$ & & & & & & \\
\hline 7. Baanonzekerheid & 2.59 & 1.17 & & & & & & & \\
\hline
\end{tabular}

$* p<.05 ; * * p<.01$

a Dummy: referentiegroep is vrouwen; ${ }^{b}$ Dummy: referentiegroep is bedienden en hogere kaderleden; ' ${ }^{\mathrm{C}}$ Dummy: referentiegroep is $35+$ 'ers.

Tabel 2 Resultaten van de mediatie-analyse met Baanonzekerheid als onafhankelijke variabele (OV), Mentaal Welzijn als afhankelijke variabele $(A V)$ en Bedreiging van de Manifeste Functie van Werk en Bedreiging van de Latente Functies van Werk als mediatoren

\begin{tabular}{|c|c|c|c|c|c|c|c|c|}
\hline \multicolumn{9}{|c|}{ Mediator } \\
\hline & \multicolumn{4}{|c|}{$\begin{array}{l}\text { Bedreiging van de manifeste } \\
\text { functie van werk }\end{array}$} & \multicolumn{4}{|c|}{$\begin{array}{l}\text { Bedreiging van de latente func- } \\
\text { ties van werk }\end{array}$} \\
\hline & B & $S D$ & $p$ & $95 \% \mathrm{Cl}$ & $B$ & $S D$ & $p$ & $95 \% \mathrm{Cl}$ \\
\hline $\begin{array}{l}\text { OV naar de mediator } \\
\text { (a-pad) }\end{array}$ & 0.19 & 0.03 & $<.001$ & & 0.08 & 0.02 & $<.001$ & \\
\hline $\begin{array}{l}\text { Direct verband tussen medi- } \\
\text { atoren en de AV (b-pad) }\end{array}$ & -0.09 & 0.03 & $<.01$ & & -0.44 & 0.05 & $<.001$ & \\
\hline $\begin{array}{l}\text { Totaal verband tussen de } \\
\text { OV en de AV (c-pad) }\end{array}$ & -0.28 & 0.03 & $<.001$ & & -0.28 & 0.03 & $<.001$ & \\
\hline $\begin{array}{l}\text { Direct verband tussen de } \\
\text { OV en de AV (c'-pad) }\end{array}$ & -0.23 & 0.03 & $<.001$ & & -0.23 & 0.03 & $<.001$ & \\
\hline Model R² (adjusted) & 0.23 & & $<.001$ & & 0.23 & & $<.001$ & \\
\hline $\begin{array}{l}\text { Indirect verband tussen de } \\
\text { OV en de AV via de voorge- } \\
\text { stelde mediator ( } a \times b-p a d)\end{array}$ & -0.02 & & & $\begin{array}{l}{[-0.04} \\
-0.002]\end{array}$ & -0.04 & & & $\begin{array}{l}{[-0.06} \\
-0.02]\end{array}$ \\
\hline
\end{tabular}

In onze eerste hypothese voorspelden we op basis van de onderzoeksliteratuur dat baanonzekerheid en mentaal welzijn negatief samenhangen. Deze hypothese werd bevestigd. Respondenten die hoger scoorden op baanonzekerheid, scoorden lager op mentaal welzijn. Deze bevinding is in overeenstemming met de bevindingen van Selenko en Batinic (2013) en Vander Elst et al. (2016), en sluit bovendien aan bij de meta-analyseresultaten van Sverke et al. (2002) en Cheng en Chan 
(2008). Baanonzekerheid is dus een stressor die veeleisend is en energie vraagt, wat zich uit in lagere scores op mentale gezondheid (De Witte et al., 2015).

Daarnaast voorspelden we dat de negatieve samenhang tussen baanonzekerheid en mentaal welzijn wordt gemedieerd door de gepercipieerde bedreiging van de manifeste functies (inkomen) en latente functies van werk (zoals sociaal contact), zoals beschreven door Jahoda (1982) in haar Latente Deprivatiemodel. Volgens Jahoda (1982) zorgt het verliezen van de baan ervoor dat deze functies niet langer vervuld worden, wat vervolgens leidt tot verminderd welzijn. Dit principe kan ook worden toegepast op baanonzekerheid. Hiervoor steunden we op de redenering dat met baanonzekerheid, of de gepercipieerde bedreiging van de baan, ook de functies van deze baan bedreigd worden (De Witte, 1999). Dit hangt samen met een verlaagd mentaal welzijn. De redenering dat een bedreiging in de toekomst (in plaats van een actuele deprivatie) van de functies voldoende kan zijn om het welzijn te verlagen, berust op de Conservation of Resources Theory (Hobfoll, 2001). Hierin wordt gesteld dat mensen gericht zijn op het verkrijgen en behouden van hulpbronnen (zoals de functies van werk). Het gevoel hebben deze hulpbronnen kwijt te zullen raken (een bedreiging), heeft een negatieve invloed op het mentaal welzijn.

Uit de resultaten bleek dat de relatie tussen baanonzekerheid en mentaal welzijn inderdaad werd gemedieerd door de bedreiging van zowel de manifeste als de latente functies van werk. Deze bevindingen liggen in lijn met de Conservation of Resources Theory (Hobfoll, 2001) en het Latente Deprivatiemodel van Jahoda (1982) en bouwen voort op de bevindingen van Selenko en Batinic (2013) en de bevindingen van Vander Elst et al. (2016). Waar Selenko en Batinic (2013) aantoonden dat het negatieve verband tussen baanonzekerheid en mentaal welzijn gemedieerd werd door de perceptie van de huidige toegang tot de manifeste en latente functies van werk, toonden wij in de huidige studie aan dat de bedreiging van de werkfuncties in de toekomst de relatie tussen baanonzekerheid en mentaal welzijn medieerde. Deze laatste conceptualisatie van de functies van werk past volgens ons beter in de context van baanonzekerheid, aangezien werknemers met baanonzekerheid nog steeds een baan hebben en dus alsnog kunnen genieten van de functies van hun baan (Vander Elst et al., 2016). Net zoals in de studie van Vander Elst et al. (2016) vonden we dat de bedreiging van de latente functie van werk het verband tussen baanonzekerheid en mentaal welzijn medieerde. Daarnaast vonden wij een mediatie-effect door bedreiging van de manifeste functie van werk, terwijl dit niet teruggevonden kon worden in de studie van Vander Elst et al. (2016). De huidige replicatiestudie gebruikte wel een andere methodologie en steekproef dan de studie van Vander Elst et al. (2016). Vander Elst et al. (2016) voerden een intrapersoonlijke toets uit, terwijl in deze replicatiestudie de verbanden op interpersoonlijk niveau onderzocht werden. Tevens maakten we in deze studie gebruik van een andere compositie van de gemeten items (bijv. een meting voor de bedreiging van de functies, meting van mentaal welzijn) en een andere, heterogene steekproef. Zo richtten Vander Elst et al. (2016) zich op de populatie van Vlaamse werknemers, terwijl wij in deze studie keken naar de ruimere populatie Belgische werknemers. 
Uit deze studie blijkt vervolgens dat de bedreiging van de manifeste functies (inkomen) en latente functies van werk (functies met een sociale betekenis, namelijk collectief doel, sociaal contact en status) een even belangrijke verklaring vormde voor het negatieve verband tussen baanonzekerheid en mentaal welzijn. Hiermee levert deze studie een bijdrage aan voorgaande studies (Selenko \& Batinic, 2013; Vander Elst et al., 2016), waarin deze contrasttest niet werd uitgevoerd. In tijden van baanonzekerheid lijkt zowel de bezorgdheid om het manifeste inkomen als de angst om de sociale voordelen van werk te verliezen in gelijke mate samen te hangen met een lagere score op mentaal welzijn.

Het bleek in deze studie te gaan om partiële mediatie-effecten: de bedreiging van de manifeste en latente functies van werk konden slechts een beperkt deel van de directe relatie tussen baanonzekerheid en mentaal welzijn verklaren. Na controle voor beide mediatoren vertoonde baanonzekerheid nog een relatief sterke relatie met mentaal welzijn. Dit is niet heel verrassend. Eerder onderzoek toonde aan dat ook andere factoren, zoals ervaren controle en breuk van het psychologisch contract, het verband tussen baanonzekerheid en mentaal welzijn mediëren (De Witte et al., 2016). Een interessant pad voor toekomstig onderzoek is daarom om de verschillende potentiële verklaringen voor de relatie tussen baanonzekerheid en mentaal welzijn samen te bestuderen, en hun relatieve verklarende belang te testen (De Witte, 2016).

Samengenomen biedt deze studie een zinvolle replicatie van resultaten uit voorgaand onderzoek naar de verklarende rol van de bedreiging van de functies van werk in de relatie tussen baanonzekerheid en mentaal welzijn (Selenko \& Batinic, 2013; Vander Elst et al., 2016). De bevindingen in deze studie bevestigen het beeld dat de bedreiging van zowel de manifeste als de latente functies van werk een mediërende rol speelt in het verband tussen baanonzekerheid en mentaal welzijn. Deze studie draagt bovendien bij aan bestaande studies door aan te tonen dat beide typen bedreiging een even sterke verklarende rol spelen.

\subsection{Beperkingen en suggesties}

Dit onderzoek heeft een aantal beperkingen. Een eerste beperking betreft het cross-sectionele onderzoeksdesign, waardoor het niet mogelijk is om uitspraken te doen over de richting van het verband tussen baanonzekerheid en mentaal welzijn. Om hierover uitspraken te doen is een longitudinale proefopzet gewenst (Taris \& Kompier, 2014). Uit een overzicht van longitudinale studies blijkt echter dat baanonzekerheid over het algemeen het welzijn beïnvloedt, eerder dan andersom (De Witte et al., 2016).

Omdat er voor de dataverzameling enkel gebruik werd gemaakt van zelf-rapportering, kan 'common-method bias' ook een beperking vormen (Conway \& Lance, 2010). Volgens de suggesties van Conway en Lance (2010) probeerden we het risico op 'common-method bias' te reduceren door het benadrukken van vrijwillige deelname en de anonieme verwerking van de gegevens. Ook toonden we de constructvaliditeit (door middel van principale componenten-analyse) en de betrouwbaarheid van de schalen aan. Een bijkomende confirmatorische factoranalyse toonde aan, zoals vermeld in het methodegedeelte, dat het gebruikte vier-factorenmodel (met de factoren baanonzekerheid, bedreiging van de manifeste functie, bedrei- 
ging van de latente functies, en mentaal welzijn) beter aansloot bij de data dan een alternatief één-factormodel. Dit suggereert dat het risico op common-method bias wellicht beperkt is. Daarnaast kunnen vragen over mentaal welzijn sociaal gevoelig liggen en vertekend worden door sociale wenselijkheid, omdat respondenten zich zo goed mogelijk pogen voor te stellen (Fisher, 1993). Door anonimiteit te garanderen werd in deze studie de kans op sociaal wenselijke antwoorden wellicht verkleind (Fisher, 1993).

Hoger geschoolden en bedienden (kantoorpersoneel) waren in deze studie oververtegenwoordigd in vergelijking met lager geschoolden en arbeiders. Aangezien uit een meta-analyse van Sverke et al. (2002) bleek dat de samenhang tussen baanonzekerheid en negatieve uitkomsten sterker was voor lager geschoolden en arbeiders, is het mogelijk dat de gevonden associaties in deze studie werden onderschat.

Een bijkomende beperking is dat slechts drie van de vijf werkfuncties die Jahoda (1982) als latente functies van werk beschouwt, werden opgenomen in dit onderzoek. Bij de factoranalyse bleken tijdstructuur en activiteit te laag op de latente factor te laden en de betrouwbaarheid van de schaal te reduceren. Enkel de bedreiging van functies met een sociale betekenis (sociaal contact, collectief doel en status) bleven over als componenten van de schaal bedreiging van de latente functies van werk. Dit beperkt de mate waarin de resultaten kunnen worden gegeneraliseerd naar alle latente functies van arbeid. Toekomstig onderzoek kan de rol van bedreiging van tijdstructuur en activiteit verder bestuderen door gebruik te maken van betrouwbare en valide schalen met meerdere items voor elke latente functie. Daarnaast is het mogelijk dat werk meer functies vervult dan de functies die Jahoda (1982) beschrijft. Toekomstig onderzoek zou ook de differentiële impact van de afzonderlijke functies van werk kunnen exploreren. Tot slot kan het interessant zijn om in toekomstig onderzoek de afzonderlijke functies van Jahoda te onderzoeken in plaats van de twee hoofddimensies. In het huidige onderzoek blijkt echter uit de factor- en betrouwbaarheidsanalyses dat de gebruikte schalen niet betrouwbaar genoeg waren om op dat niveau uitspraken te kunnen doen.

\section{Conclusie}

In deze replicatiestudie werden bevindingen uit eerder onderzoek van Selenko en Batinic (2012) en Vander Elst et al. (2016) opnieuw onderzocht en bevestigd. Zo werd bevestigd dat baanonzekerheid en mentaal welzijn op negatieve wijze samenhangen. Ook werd aangetoond dat het negatieve verband tussen baanonzekerheid en mentaal welzijn gemedieerd wordt door de bedreiging van de manifeste en latente functies van werk. Meer concreet ging het hierbij om de perceptie van de toekomstige bedreiging van de manifeste en latente functies van werk. Uit de huidige studie bleek ook dat de bedreiging van de manifeste en latente functies van werk een ongeveer even belangrijke verklaring vormden voor het negatieve verband tussen baanonzekerheid en mentaal welzijn. Op basis van deze bevindingen kunnen interventiestrategieën ontwikkeld worden, zoals het aansporen van deel- 
name aan sociale activiteiten buiten het werk door de overheid, die het negatieve verband tussen baanonzekerheid en mentaal welzijn afzwakken.

\section{Praktijkbox}

Wat betekenen de resultaten voor de praktijk?

- De samenhang tussen baanonzekerheid en het mentaal welzijn kan mogelijk worden afgezwakt door werknemers aan te sporen om deel te nemen aan sociale activiteiten buiten het werk. Via die activiteiten zouden ze, onafhankelijk van hun baan, een sociaal netwerk kunnen uitbouwen, status verwerven en zich betrokken voelen bij de samenleving. Daardoor kan worden tegemoetgekomen aan de latente functies van werk, waardoor het welzijn zou worden versterkt. We zien een belangrijke rol weggelegd voor de overheid in het motiveren van mensen om deel te nemen aan sociale activiteiten.

- Niet enkel buiten het werk, maar ook op de werkvloer kunnen initiatieven worden genomen. Naar de werknemers toe duidelijk communiceren over eventuele organisatieveranderingen of gebeurtenissen en hen bij deze veranderingen betrekken kan het gevoel van baanonzekerheid doen afnemen en dus de negatieve gevolgen ervan verminderen (Schweiger \& Denisi, 1991; Mikkelsen, Saksvik \& Landsbergis, 2000).

\section{Noot}

1 In België is er geen betekenisverschil tussen 'helemaal (niet) akkoord' en 'helemaal mee eens'/'helemaal mee oneens'.

\section{Literatuur}

Baksheev, G.N., Robinson, J., Cosgrave, E.M., Baker, K., \& Yung, A.R. (2011). Validity of the 12-item General Health Questionnaire (GHQ-12) in detecting depressive and anxiety disorders among high school students. Psychiatry Research, 187(1), 291-296. doi:10.1016/j.psychres.2010.10.010

Berwick, D.M., Murphy, J.M., Goldman, P.A., Ware Jr, J.E., Barsky, A.J., \& Weinstein, M.C. (1991). Performance of a five-item mental health screening test. Medical Care, 29(2), 169-176. doi:10.1097/00005650-199102000-00008

Borg, I., \& Elizur, D. (1992). Job insecurity: Correlates, moderators and measurement. International Journal of Manpower, 13(2), 13-26. doi:10.1108/01437729210010210

Cheng, G.H.L., \& Chan, D.K.S. (2008). Who suffers more from job insecurity? A meta-analytic review. Applied Psychology: An International Review, 57(2), 272-303. doi:10.1111/j.1464-0597.2007.00312.x

Conway, J.M., \& Lance, C.E. (2010). What reviewers should expect from authors regarding common method bias in organizational research. Journal of Business and Psychology, 25, 325-334. doi:10.1007/s10869-010-9181-6 
Dekker, S., \& Schaufeli, W. (1995). The effects of job insecurity on psychological health and withdrawal: A longitudinal study. Australian Psychologist, 30(1), 57-63. doi:10.1080/00050069508259607

De Witte, H. (1999). Job insecurity and psychological well-being: Review of the literature and exploration of some unresolved issues. European Journal of Work and Organizational Psychology, 8(2), 155-177. doi:10.1080/135943299398302

De Witte, H. (2000). Arbeidsethos en baanonzekerheid: meting en gevolgen voor welzijn, tevredenheid en inzet op het werk. In R. Bouwen, K. De Witte, H. De Witte, \& T. Tailleu (Red.), Van groep naar gemeenschap: Liber Amicorum Prof. Dr. L. Lagrou (p. 325350). Leuven: Garant.

De Witte, H. (2016). On the scarring effects of job insecurity (and how they can be explained). Scandinavian Journal of Work, Environment \& Health, 42(2), 99-102. doi:10.5271/sjweh.3545

De Witte, H., Pienaar, J., \& De Cuyper, N. (2016). Review of 30 years of longitudinal studies on the association between job insecurity and health and well-being. Is there causal evidence? Australian Psychologist, 51(1), 18-31. doi:10.1111/ap.12176

De Witte, H. \& Van den Broeck, A. (2011). Arbeid in het nieuwe millennium: van verplichting tot ontplooiing? In K. Abts, K. Dobbelaere, \& L. Voyé (Red.), Nieuwe tijden, nieuwe mensen. Belgen over arbeid, gezin, ethiek, religie en politiek (p. 71-104). Tielt: Lannoo.

De Witte, H., Vander Elst, T., \& De Cuyper, N. (2015). Job insecurity, health and well-being. In J. Vuori, R. Blonk, \& R.H. Price (Eds.), Sustainable working lives: Managing work transitions and health throughout the life course (pp. 109-128). New York: Springer.

Ferrie, J., Shipley, M., Marmot, M., Stansfeld, S., \& Smith, G. (1995). Health effects of anticipation of job change and non-employment: Longitudinal data from the Whitehall II study. British Medical Journal, 311(7015), 1264-1269. doi:10.1136/ bmj.311.7015.1264

Fisher, R.J. (1993). Social desirability bias and the validity of indirect questioning. Journal of Consumer Research, 20(2), 303-315. doi:10.1086/209351

Goldberg, D.P. (1978). Manual of the General Health Questionnaire. Windsor: National Foundation for Educational Research.

Greenhalgh, L., \& Rosenblatt, Z. (1984). Job insecurity: Toward conceptual clarity. The Academy of Management Review, 9(3), 438-448. doi:10.2307/258284

Handaja, Y., \& De Witte, H. (2006). De impact van kwantitatieve en kwalitatieve baanonzekerheid op het welzijn. Over.Werk. Tijdschrift van het Steunpunt WAV, 16(4), 150-157.

Hellgren, J., \& Sverke, M. (2003). Does job insecurity lead to impaired well-being or vice versa? Estimation of cross-lagged effects using latent variable modelling. Journal of Organizational Behavior, 24(2), 215-236. doi:10.1002/job.184

Hellgren, J., Sverke, M., \& Isaksson, K. (1999). A two-dimensional approach to job insecurity: Consequences for employee attitudes and well-being. European Journal of Work and Organizational Psychology, 8(2), 179-195. doi:10.1080/135943299398311

Hobfoll, S.E. (2001). The influence of culture, community, and the nested-self in the stress process: Advancing conservation of resources theory. Applied Psychology, 50(3), 337-421. doi:10.1111/1464-0597.00062

Jahoda, M. (1982). Employment and unemployment: A social-psychological analysis. Cambridge: Cambridge University Press.

Mikkelsen, A., Saksvik, P.Ø., \& Landsbergis, P. (2000). The impact of a participatory organizational intervention on job stress in community health care institutions. Work \& Stress, 14(2), 156-170. doi:10.1080/026783700750051667

Muller, J.J., Creed, P.A., Waters, L.E., \& Machin, M.A. (2005). The development and preliminary testing of a scale to measure the latent and manifest benefits of employment. 
European Journal of Psychological Assessment, 21(3), 191-198. doi:10.1027/10155759.21.3.191

Preacher, K.J., \& Hayes, A.F. (2008). Asymptotic and resampling strategies for assessing and comparing indirect effects in multiple mediator models. Behavior Research Methods, 40(3), 879-891. doi:10.3758/brm.40.3.879

Schweiger, D.M., \& Denisi, A.S. (1991). Communication with employees following a merger: A longitudinal field experiment. Academy of Management Journal, 34(1), 110-135. doi:10.2307/256304

Selenko, E., \& Batinic, B. (2013). Job insecurity and the benefits of work. European Journal of Work and Organizational Psychology, 22(6), 725-736. doi:10.1080/1359432x.2012.703376

Shoss, M. K. (2017). Job insecurity: An integrative review and agenda for future research. Journal of Management, 43(6), 1911-1939. doi:10.1177/0149206317691574

Sverke, M., Hellgren, J., \& Näswall, K. (2002). No security: A meta-analysis and review of job insecurity and its consequences. Journal of Occupational Health Psychology, 7(3), 242-264. doi:10.1037/1076-8998.7.3.242

Taris, T., \& Kompier, M. (2014). Cause and effect: Optimizing the designs of longitudinal studies in occupational health psychology. Work \& Stress, 28, 1-8. doi:10.1080/02678373 .2014 .878494

Vander Elst, T., De Witte, H., \& De Cuyper, N. (2014). The Job Insecurity Scale: A psychometric evaluation across five European countries. European Journal of Work and Organizational Psychology, 23(3), 364-380. doi:10.1080/1359432X.2012.745989

Vander Elst, T., Näswall, K., Bernhard-Oettel, C., De Witte, H., \& Sverke, M. (2016). The effect of job insecurity on employee health complaints: A within-person analysis of the explanatory role of threats to the manifest and latent benefits of work. Journal of Occupational Health Psychology, 21(1), 65-76. doi:10.1037/aoo39140

Van Vuuren, T. (1990). Met ontslag bedreigd: Werknemers in onzekerheid over hun arbeidsplaats bij veranderingen in de organisatie. Amsterdam: VU Uitgeverij.

\section{Job insecurity and mental well-being: mediated by the threat of Jahoda's functions of work?}

\section{S. Margerin, T. Vander Elst, H. Van Coillie, H. Verlinden \& H. De Witte, Gedrag \& Organisatie, volume 31, June 2018, nr. 2, pp. 79-95}

In this study, we examined whether the negative relationship between perceived job insecurity and mental well-being is mediated by the threat of Jahoda's manifest benefits (e.g., income) and the latent benefits of work (e.g., social contact, status). The experienced threat of job loss means a threat to the benefits of work, which can result in a lower well-being among employees. This study replicates the studies of Selenko and Batinic (2013) and Vander Elst, Näswall, Bernhard-Oettel, De Witte and Sverke (2015), but uses a different research design and methodology. In total, 788 Belgian employees participated in this study, using a cross-sectional questionnaire study. As expected, the threat of the manifest and latent benefits of work mediated in about equal measure the relationship between job insecurity and mental health. These results correspond with the findings in the literature and validate the importance of threatened work benefits as an explanation for the negative relationship between job insecurity and mental health. Our findings may promote the development 
of intervention strategies to weaken the negative relationship between job insecurity and mental health, for example, by encouraging social activities that are not related to work.

Key words: job insecurity, mental well-being, manifest benefits of work, latent benefits of work, replication study 